\title{
The Enzymic Interconversion of Acetate and Acetyl-coenzyme A in Escherichia coli
}

\author{
By T. D. K. BROWN \\ Wolfson Laboratory for Molecular Pathology, Garscube Estate, Bearsden, \\ Glasgow G6i \\ M. C. JONES-MORTIMER AND H. L. KORNBERG \\ Department of Biochemistry, University of Cambridge, Cambridge CB2 I $Q W$
}

(Received Iо May 1977)

Mutants of Escherichia coli $\mathrm{K} 12$ have been isolated that grow on media containing pyruvate or proline as sole carbon sources despite the presence of 10 or 50 mM-sodium fluoroacetate. Such mutants lack either acetate kinase [ATP:acetate phosphotransferase; EC 2.7.2. I] or phosphotransacetylase [acetyl-CoA:orthophosphate acetyltransferase; EC 2.3.I.8] activity. Unlike wild-type $E$. coli, phosphotransacetylase mutants do not excrete acetate when growing aerobically or anaerobically on glucose; their anaerobic growth on this sugar is slow. The genes that specify acetate kinase $(a c k)$ and phosphotransacetylase (pta) activities are cotransducible with each other and with purF and are thus located at about min 50 on the $E$. coli linkage map. Although $\mathrm{Pta}^{-}$and Ack ${ }^{-}$mutants are greatly impaired in their growth on acetate, they incorporate $\left[2{ }^{-14} \mathrm{C}\right]$ acetate added to cultures growing on glycerol, but not on glucose. An inducible acetyl-CoA synthetase [acetate:CoA ligase (AMPforming); EC 6.2.I.I] effects this uptake of acetate.

\section{INTRODUCTION}

The metabolic utilization of acetate, whether for biosynthesis of lipids or for oxidation via the tricarboxylic acid cycle, requires first that it be activated to acetyl-coenzyme A. Two main mechanisms have been elucidated that bring about this conversion. In one, used by eukaryotic cells as well as by some bacteria, acetyl-CoA synthetase [acetate: CoA ligase (AMP-forming); EC 6.2.1 . I] effects the acetylation of coenzyme A concomitant with the cleavage of ATP to AMP and inorganic pyrophosphate (Chou \& Lipmann, 1952; Berg, 1956). In the second, which appears to be restricted to bacteria (Lipmann, 1944; Kaplan \& Lipmann, I948; Stadtman \& Barker, 1950), two enzymes catalyse (i) the conversion of acetate to acetyl phosphate, with cleavage of ATP to ADP, and (ii) the transfer of the acetyl moiety from acetyl phosphate to coenzyme $\mathbf{A}$, with liberation of inorganic phosphate.

$$
\begin{aligned}
\text { acetate }+\mathrm{ATP} & \rightleftharpoons \text { acetyl phosphate }+\mathrm{ADP} \\
\text { acetyl phosphate }+\mathrm{CoA} . \mathrm{SH} & \rightleftharpoons \text { acetyl-S. CoA + inorganic phosphate }
\end{aligned}
$$

The enzyme catalysing reaction (i), acetate kinase [ATP:acetate phosphotransferase; EC 2.7.2. I] has been highly purified from extracts of Escherichia coli (Rose et al., 1954). It is abundantly present in the organisms, even when the cells have not previously been exposed to acetate. This makes it difficult to ascertain whether acetyl-CoA synthetase is also present, and leaves open the physiological role of acetate kinase.

To resolve these questions, we have isolated mutants of $E$. coli K12 that are resistant to 
high concentrations of fluoroacetate when growing on pyruvate or proline, under which conditions the growth of wild-type cells is strongly inhibited, on the assumption that many of these mutants owe their tolerance of fluoroacetate to changes in the system(s) that effect the uptake of the substituted acetate or its activation to fluoroacetyl-coenzyme A (Marcus \& Elliott, 1959), and that these changes also affect the metabolism of acetate. We report the properties of such mutants and the location of the genes affected on the $E$. coli genome.

\section{METHODS}

Organisms. These are listed in Table $\mathrm{I}$. With the exception of ack and pta, introduced in this paper, the abbreviations for genetical markers are those used by Bachmann, Low \& Taylor (1976). Aerobically, cells were grown at $37^{\circ} \mathrm{C}$ in defined liquid media containing salts (Ashworth \& Kornberg, 1966) and a carbon source at $25 \mathrm{~mm}$ unless otherwise stated; the media were supplemented as appropriate with required L-amino acids, or adenine, at $80 \mu \mathrm{g} \mathrm{ml}^{-1}$. Solid media were the same, but solidified with $1 \cdot 5 \%(\mathrm{w} / \mathrm{v})$ Oxoid agar no. $\mathbf{I}$.

Anaerobically, cells were grown in two ways. (i) For the production of cells for enzyme assays, a small aerobically-grown inoculum was transferred to a flask completely filled with freshly autoclaved medium. A 'Subaseal' stopper was used to seal the flask. The maintenance of anaerobiosis was monitored by addition of a small quantity of methylene blue. (ii) For growth studies, the cells were grown in $250 \mathrm{ml}$ Erlenmeyer flasks fitted with glass spargers and were sparged continuously with $\mathrm{N}_{2} / \mathrm{CO}_{2}(95: 5, \mathrm{v} / \mathrm{v})$. Samples were removed anaerobically for growth measurements. In all anaerobic experiments, sodium bicarbonate $(25 \mathrm{~mm})$ was added to the medium.

Growth was measured as the extinction of cell suspensions at $680 \mathrm{~nm}$; an $E_{880}$ of $1 \cdot 0$ was taken to represent $0.68 \mathrm{mg}$ dry mass $\mathrm{ml}^{-1}$ (Ashworth \& Kornberg, 1966; Kornberg \& Reeves, 1972).

Assay of enzymes. For measurements of enzyme activities in aerobically-grown cells, cultures were grown in $50 \mathrm{ml}$ medium in $250 \mathrm{ml}$ Erlenmeyer flasks with vigorous shaking, to an $E_{680}$ of approximately $\mathrm{I}$. For measurements of activities in anaerobically-grown cells, cultures were grown in $100 \mathrm{ml}$ medium to an $E_{680}$ of approximately 0.6 . Cultures were harvested by centrifuging at $3000 \mathrm{~g}$ for $10 \mathrm{~min}$ at $4{ }^{\circ} \mathrm{C}$; the cells were washed twice with $10 \mathrm{~mm}$-sodium phosphate buffer $\mathrm{pH} 7.5$ containing $10 \mathrm{mM}-\mathrm{MgCl}_{2}$ and I mM-EDTA. They were resuspended in $5 \mathrm{ml}$ of this buffer and disrupted for $1.5 \mathrm{~min}$ in an M.S.E. $150 \mathrm{~W}$ sonicator operating at maximum output, the cell suspension being held in an ice bath during this procedure. The cell extracts were centrifuged for $\mathrm{I} h$ at $25000 \mathrm{~g}$ to reduce the NADH oxidase levels for the phosphotransacetylase assays.

Acetate kinase was assayed at $30^{\circ} \mathrm{C}$ in the direction of acetate phosphorylation by the method of Rose et al. (1954). Frequent checks were made to ensure that acetyl hydroxamate formation with time was linear over the period of the assay, and that the amounts of hydroxamate formed were stoicheiometrically related to the quantities of cell-free extract added. A standard curve for acetyl hydroxamate was prepared using lithium acetyl phosphate as acetyl donor.

Phosphotransacetylase [acetyl-CoA:orthophosphate acetyltransferase; EC 2.3.1.8] was measured by a modification of an assay for citrate synthase (Ochoa, 1955). The formation of acetyl-CoA from acetyl phosphate and coenzyme $\mathrm{A}$ was measured as the reduction of $\mathrm{NAD}^{+}$in the presence of $\mathrm{L}$-malate, malate dehydrogenase [L-malate: $\mathrm{NAD}^{+}$oxidoreductase; EC I.I.I.37] and citrate synthase [citrate oxaloacetate-lyase (CoA-acetylating); EC 4.1.3.7]. The reaction mixture (I ml) contained: $100 \mu \mathrm{mol} \mathrm{Tris/HCl} \mathrm{pH} \mathrm{8.0;} 5 \mu \mathrm{mol}$ $\mathrm{MgCl}_{2} ; 0.5 \mu \mathrm{mol} \mathrm{NAD} ; 0.5 \mu \mathrm{mol}$ coenzyme A; $5 \mu \mathrm{mol} \mathrm{L}$-malate; $12.5 \mu \mathrm{g}$ crystalline malate dehydrogenase; $25 \mu \mathrm{g}$ crystalline citrate synthase; Io $\mu \mathrm{mol}$ lithium acetyl phosphate; and cell-free extract. The assays were carried out at 22 to $25^{\circ} \mathrm{C}$. Care was taken to keep the rates of NADH production within stoicheiometric limits. The assay is capable of detecting a rate of about $0.03 \mu \mathrm{mol}$ NADH formed $\mathrm{min}^{-1}$.

Acetyl phosphate phosphatase activity was measured by following the disappearance of acetyl hydroxamateforming material using the method described by Lipmann \& Tuttle (1945). The assays were carried out either at $\mathrm{pH} 5.65$ in $0.09 \mathrm{M}$-sodium acetate buffer, or at $\mathrm{pH} 7.4$ in $0.1 \mathrm{M}-\mathrm{Tris} / \mathrm{HCl}$ buffer. In both assays the reaction mixture contained $5 \mathrm{~mm}-\mathrm{MgCl}_{2}$ and $5 \mathrm{~mm}$-lithium acetyl phosphate. Samples were withdrawn over a period of $60 \mathrm{~min}$ and the residual acetyl phosphate was measured.

Acetyl-CoA synthetase activity was measured in two ways. (i) Hydroxamate method. The routine assay was based on that of Jones \& Lipmann (1955). The reaction mixture $(3 \mathrm{ml})$ contained: $150 \mu \mathrm{mol}$ Tris/ $\mathrm{HCl}$ pH 8.5; about $300 \mu \mathrm{mol}$ hydroxylamine hydrochloride neutralized with ammonia to $\mathrm{pH} 8.5 ; 15 \mu \mathrm{mol}$ $\mathrm{MgCl}_{2} ; 15 \mu \mathrm{mol}$ sodium acetate; $1 \mu \mathrm{mol}$ coenzyme A; $10 \mu \mathrm{mol}$ ATP disodium salt; and cell-free extract. The reaction was initiated by the addition of ATP, incubated for $\mathrm{I} \mathrm{h}$ at $37^{\circ} \mathrm{C}$, and then terminated by the addition of $3 \mathrm{ml}$ of $2.5 \%(\mathrm{w} / \mathrm{v}) \mathrm{FeCl}_{3}$ in $2 \mathrm{M}-\mathrm{HCl}$ containing $10 \%(\mathrm{v} / \mathrm{v})$ perchloric acid. Precipitated protein was removerl by centrifuging in a bench centrifuge and the absorbance was measured at $520 \mathrm{~nm}$ with a Uni- 
Table I. Escherichia coli $\mathrm{KI} 2$ strains used

\begin{tabular}{|c|c|c|}
\hline Organism & Relevant genetic markers & Reference or source \\
\hline $\begin{array}{l}\text { Hfr strains } \\
\text { KLI6 } \\
\text { KL96 } \\
\text { PK I91 } \\
\text { KK492 }\end{array}$ & $\begin{array}{l}\text { prototroph } \\
\text { prototroph } \\
\text { pro lac } X I I I \\
\text { met thy } A \text { ack }\end{array}$ & $\begin{array}{l}\text { CGSC* } \\
\text { CGSC } \\
\text { CGSC } \\
\text { This paper }\end{array}$ \\
\hline $\begin{array}{c}\text { F- }^{-} \text {strains } \\
\text { JM448 } \\
\text { AB2557 } \\
\text { PA309 } \\
\text { JM591 } \\
\text { JM592 } \\
\text { K2.3 }\end{array}$ & $\begin{array}{l}\text { argH phe A purF fpk str } \\
\text { ilv dsdA aroC purF str } \\
\text { trp his argH thr leu str } \\
\text { trp his argH thr leu ack str } \\
\text { trp his argH thr leu pta str } \\
\text { trp his argH aceF str }\end{array}$ & $\begin{array}{l}\text { Jones-Mortimer \& Kornberg } \\
\text { (1974) } \\
\text { CGSC } \\
\text { Laboratory stock } \\
\text { This paper } \\
\text { This paper } \\
\text { Laboratory stock }\end{array}$ \\
\hline
\end{tabular}

* Coli Genetic Stock Center, Yale University School of Medicine, 310 Cedar Street, New Haven, Connecticut 06510 , U.S.A.

cam SP600 spectrophotometer, within 30 min of completion of the reaction. Lithium acetyl phosphate was used to prepare a standard curve. The assay was linearly dependent on enzyme addition up to a rate of about $2 \mu \mathrm{mol} \mathrm{h}^{-1}$ and linear with time over at least I h. Blanks without coenzyme A and ATP were prepared for each set of determinations.

(ii) Continuous coupled assay. This was carried out at $25^{\circ} \mathrm{C}$ in essentially the same way as the phosphotransacetylase assay except that $10 \mu \mathrm{mol}$ acetate and $10 \mu \mathrm{mol}$ ATP were substituted for acetyl phosphate.

Protein was estimated in cell-free extracts by the method of Lowry et al. (1951). Bovine serum albumin was used as a standard.

Measurement of the incorporation of ${ }^{14} \mathrm{C}$ from $\left[{ }^{14} \mathrm{C}\right] a c e t a t e$ by cells growing on unlabelled carbon sources. Washed cell suspensions were inoculated at low cell densities into media containing an unlabelled carbon source and $\left[{ }^{14} \mathrm{C}\right]$ acetate. Samples $(0.5 \mathrm{ml})$ taken during exponential growth were filtered through Sartorius nitrocellulose filters $(0.45 \mu \mathrm{m}$ pore size), and the filters were washed with $5 \mathrm{ml}$ of carbon source-free medium. The filtered cells and filters were placed in $10 \mathrm{ml}$ toluene/methanol scintillant [toluene/methanol $(7: 3, \mathrm{v} / \mathrm{v})$ containing $0.4 \%(w / v) ~ 2,5$-diphenyloxazole and $0.02 \%(w / v)$ I,4-di-2-(5-phenyloxazolyl)benzene] and their radioactivity was measured for a total of at least 5000 counts. Samples of the cultures were also taken at the beginning and end of each experiment to assess the extent of oxidation of added label to volatile products. These samples were placed in $10 \mathrm{ml}$ toluene/methanol scintillant with a dry nitrocellulose filter. The radioactivity of all samples was measured with a Packard 4000 liquid scintillation counter.

Estimation of acetate concentration in the medium. Samples were taken from the culture at different times during exponential growth and centrifuged to remove the bacteria. The supernatant solutions were stored at $-20^{\circ} \mathrm{C}$. Immediately before analysis they were acidified with orthophosphoric acid. Acetate was estimated with a Pye Series 104 gas chromatograph, fitted with a column of $10 \%$ diethylene glycol adipate on $100 / 200$ mesh phosphoric acid-treated Diatomite $\mathbf{C}$, and a flame ionization detector. Standard acetate solutions were run before and after each series of estimations. The areas under the peaks were estimated by planimetry.

Genetical procedures. The genetical methods employed were those listed by Miller (1972) and Low (1973).

Reagents. Acetyl phosphate lithium salt, ATP disodium salt, coenzyme A and NAD were obtained from Sigma; sodium fluoroacetate was from Sigma or BDH; sodium pyruvate, citrate synthase and malate dehydrogenase were from Boehringer; [2-14C]acetate sodium salt was from The Radiochemical Centre, Amersham. Other chemicals were analytical reagent grade where available.

\section{RESULTS}

\section{Isolation and properties of mutants}

As had been noted previously by Mager, Goldblum-Sinai \& Blank (1955), the toxicity of fluoroacetate to $E$. coli $\mathrm{KI} 2$ was relatively low when the organisms were growing on glucose, glycerol or L-malate. Considerably greater inhibition of growth was observed when the carbon source was pyruvate or proline. Selection of mutants resistant to fluoroacetate was 


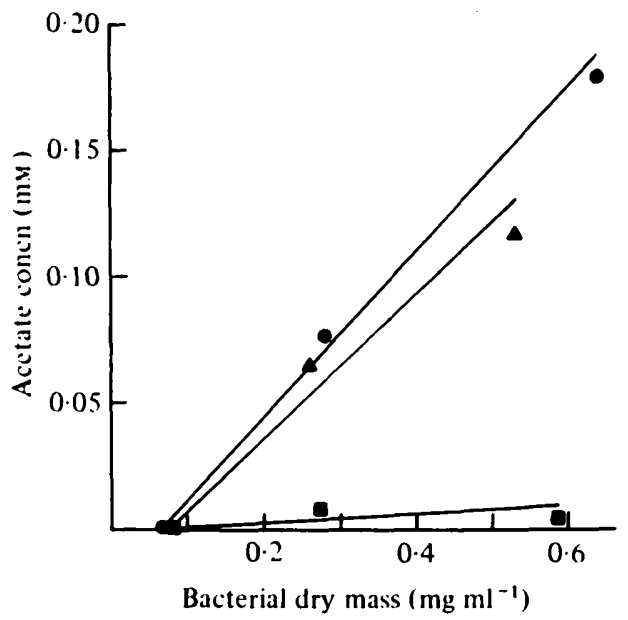

Fig. I. Appearance of acetate in the medium during the aerobic growth on glucose of $E$. coli strain PA309 (৫) and its mutants JM59I (४), deficient in acetate kinase, and JM592 (E), deficient in phosphotransacetylase activity.

Table 2. Growth of E. coli $\mathrm{KI} 2$ strains at $37^{\circ} \mathrm{C}$

Mean doubling time $(\mathrm{h})$ of strain:

Carbon source

Glucose

Glucose + bicarbonate

Acetate
Condition

Aerobic

Anaerobic

Aerobic

$\begin{array}{cccc}\text { PA309 } & \text { JM59I } & \text { JM592 } & \text { KK492 } \\ \text { I.O } & \mathrm{I} \cdot 0 & \mathrm{I} \cdot 0 & \mathrm{I} \cdot 0 \\ \mathrm{I} \cdot 8 & \mathrm{I} \cdot 8 & 3.8 & 2 \cdot 3 \\ 2.8 & 6.0 & >15 & 5.5\end{array}$

Table 3. Specific activities of acetate kinase and phosphotransacetylase in extracts of glucose-grown E. coli KI 2 strain PA309 and its mutants

Specific activities are expressed as $\mu$ mol hydroxamate or NADH formed min $^{-1}$ (mg protein) $)^{-1}$.

\begin{tabular}{|c|c|c|c|}
\hline \multirow[b]{2}{*}{ Growth condition } & \multirow[b]{2}{*}{ Organism } & \multicolumn{2}{|c|}{ Specific activity } \\
\hline & & $\begin{array}{c}\text { Acetate } \\
\text { kinase }\end{array}$ & $\begin{array}{l}\text { Phosphotrans- } \\
\text { acetylase }\end{array}$ \\
\hline Aerobic, at $37^{\circ} \mathrm{C}$ (glucose) & $\begin{array}{l}\text { PA309 } \\
\text { JM591 } \\
\text { JM592 }\end{array}$ & $\begin{array}{l}1.8 \\
0.1 \\
I .7\end{array}$ & $\begin{array}{c}2.0 \\
1.9 \\
<0.03\end{array}$ \\
\hline $\begin{array}{l}\text { Anaerobic, at } 37^{\circ} \mathrm{C} \\
\quad \text { (glucose + bicarbonate) }\end{array}$ & $\begin{array}{l}\text { PA309 } \\
\text { JM59I } \\
\text { JM592 }\end{array}$ & $\begin{array}{c}4.2 \\
0.4 \\
\text { not tested }\end{array}$ & $\begin{array}{r}5.4 \\
5.2 \\
<0.1\end{array}$ \\
\hline
\end{tabular}

therefore carried out on agar plates containing either $25 \mathrm{~mm}$-pyruvate or $10 \mathrm{~mm}$-proline, together with sodium fluoroacetate at 10 or $50 \mathrm{mM}$. Between 50 and 100 such mutants grew at $37^{\circ} \mathrm{C}$ in $48 \mathrm{~h}$ when samples of $E$. coli cultures in nutrient broth (containing approx. $10^{8}$ cells) were plated on these media; the mutants were picked, purified be repeated isolation of single colonies, and tested for their ability to grow on acetate as sole carbon source. Representative colonies of any that grew poorly or not at all on this substrate, but grew well on pyruvate, glycerol and glucose, were tested further.

Two main classes of fluoroacetate-resistant mutants were obtained. One class, of which strain JM59I is representative, grew perceptibly in $24 \mathrm{~h}$ on agar plates containing acetate as sole carbon source and, in liquid culture, grew with a mean doubling time of $6 \mathrm{~h}$ on this substrate (Table 2). Mutants of this type had virtually no acetate kinase activity (Table 3 ). 

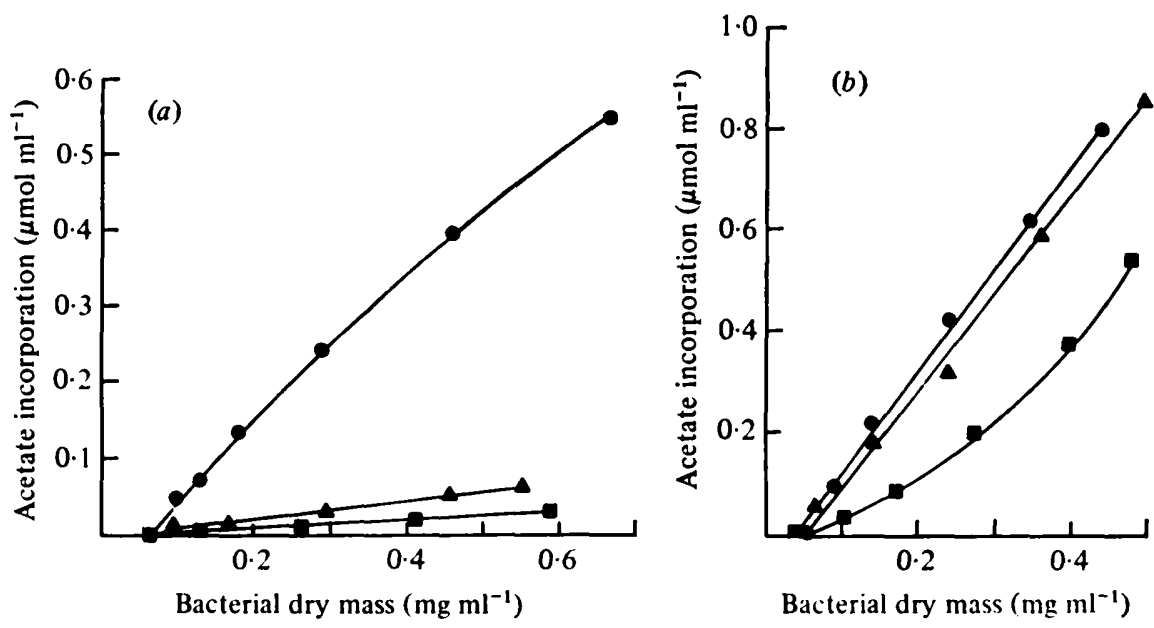

Fig. 2. Incorporation of ${ }^{14} \mathrm{C}$ from $2 \mathrm{~mm}$-sodium $\left[2-{ }^{14} \mathrm{C}\right.$ ]acetate added to cultures of $E$. coli strain PA309 (O) and its mutants JM591 (A) and JM592 (ם) growing aerobically on (a) 25 mM-glucose or (b) 25 mM-glycerol.

The second type of fluoroacetate-resistant mutant, of which strain JM592 is representative, did not grow on agar plates containing acetate as carbon source and had a mean doubling time of over $15 \mathrm{~h}$ in acetate growth medium (Table 2); extracts of this class of mutant were devoid of phosphotransacetylase activity (Table 3). None of the mutants we have characterized (including four amber mutants) had lost both acetate kinase and phosphotransacetylase activities.

Mutants deficient in phosphotransacetylase activity differed both from wild-type $E$. coli and from mutants impaired in acetate kinase in their metabolism of glucose. Although no differences were observed in their doubling time when growing aerobically on glucose (Table 2), the phosphotransacetylase lesion was manifested under these conditions by a virtual absence of acetate excretion into the growth medium (Fig. I). Essentially similar results were obtained with cells growing anaerobically on glucose plus bicarbonate, although the yield of acetate was about five times greater; under these conditions, the phosphotransacetylase mutants grew at less than a half of the rate at which wild-type $E$. coli or its acetate kinase mutants grew (Table 2).

When sodium $\left[2-{ }^{14} \mathrm{C}\right]$ acetate was added to cultures of wild-type $E$. coli growing aerobically on glucose, the labelled material was taken up and incorporated into cell components (Fig. 2a). However, little or no isotope was incorporated under these conditions by either of the two types of mutant. In contrast, the acetate kinase mutant took up $\left[2-{ }^{14} \mathrm{C}\right] \mathrm{acetate}$ as readily as did its wild-type parent when glycerol was the carbon source for growth and, after a lag, so did the phosphotransacetylase mutant (Fig. $2 b$ ). This shows that the impairment of $\left[2-{ }^{14} \mathrm{C}\right]$ acetate incorporation by the two types of mutant is not due to a raised intracellular concentration of acetyl-CoA or acetyl phosphate, since this would be as likely to occur during growth on glycerol as during growth on glucose. However, the addition of glucose to a culture of the mutant impaired in acetate kinase activity whilst it grew on glycerol had little effect on the incorporation of $\left[2-{ }^{14} \mathrm{C}\right]$ acetate (Fig. 3 ), which suggests that glucose represses the synthesis of the system(s) that still permits the incorporation of $\left[2-{ }^{14} \mathrm{C}\right]$ acetate into the mutants rather than inhibiting its activity.

\section{Identification and properties of acetyl-CoA synthetase}

The high activities of acetate kinase in extracts of wild-type $E$. coli make it difficult to detect the presence of acetyl-CoA synthetase. This difficulty is removed by the use of mutants 


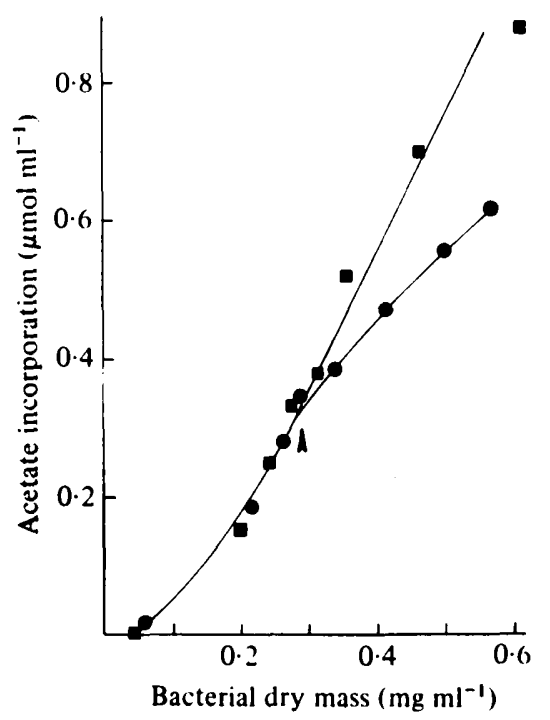

Fig. 3. The effect of adding $25 \mathrm{~mm}$-glucose on the incorporation of ${ }^{14} \mathrm{C}$ by the acetate kinase mutant $E$. coli strain JM59 I growing on 25 mM-glycerol plus 2 mM-sodium [2-14C]acetate. Glucose was added to one flask (e) as indicated by the arrow.

Table 4. Requirement for acetyl-CoA synthetase activity in extracts of the ack mutant $E$. coli KI 2 strain KK492

Cell-free extract was prepared from cells grown in a medium containing 20 mm-glycerol plus 25 mM-acetate as carbon source. Specific activity is expressed as nmol acetyl hydroxamate formed $\mathrm{min}^{-1}(\mathrm{mg} \text { protein })^{-1}$.

$\begin{array}{lc}\text { Contents of assay mixture } & \text { Specific activity } \\ \text { Complete } & 54.3 \\ \text { - Acetate } & 0.8 \\ \text {-CoA } & 0.8 \\ \text {-ATP } & 0 \\ \text { - } \mathrm{MgCl}_{2} & 32 \cdot 1 \\ \text { - } \mathrm{MgCl}_{2}+3.3 \mathrm{~mm}-\mathrm{EDTA} & 0.8 \\ \text { +3.3 mM-2-Mercaptoethanol } & 44.4 \\ \text {-ATP+3.3 mM-GTP } & 5.7 \\ \text { +Triton X-100 (1.6 mg ml-1) } & 53.3\end{array}$

impaired in acetate kinase activity. In one such mutant, strain KK492, no acetate kinase activity was detected; however, acetyl-CoA was formed from acetate and ATP when coenzyme A was also added (Table 4). The formation of the hydroxamate in assay (i) (see Methods) required the presence of all the components of the acetyl-CoA synthetase reaction: little or none was formed in the absence of acetate, of ATP or of coenzyme A, and the inhibition produced by EDTA also implied the need for $\mathrm{Mg}^{2+}$. GTP did not substitute for ATP; unlike the fatty acyl-CoA synthetase described by Overath, Pauli \& Schairer (1969), neither mercaptoethanol nor Triton X-I00 stimulated the activity of this enzyme. Enzymic activity was also not affected significantly by the inclusion in the assay system of possible effectors such as Io mM-pyruvate, or Io mM-phosphoenolpyruvate, or I mM-ADP, or I mM-AMP, or I mM-NADH. Some competition between acetate and propionate was observed.

The enzymic activity appeared not to be membrane-bound: over $95 \%$ of the activity of a crude cell-free extract was recovered in the supernatant solution after centrifuging at I $20000 \mathrm{~g}$ for $3 \mathrm{~h}$. This solution could be stored at $-20^{\circ} \mathrm{C}$ for a week without loss of activity. In both assays (i) and (ii) (see Methods), the enzyme was optimally active at $\mathrm{pH} 8.5$, which 
Table 5. Specific activity of acetyl-CoA synthetase in extracts of E. coli KI 2 strain KK492 grown on various carbon sources

Cultures were grown, cell-free extracts were prepared and acetyl-CoA synthetase was assayed as described in Methods, except that $5 \mathrm{~mm}$-sodium acetate and $0.22 \mathrm{~mm}$-coenzyme $A$ were used in the assays. Specific activity is expressed as nmol acetyl hydroxamate formed $\mathrm{min}^{-1}$ (mg protein) ${ }^{-1}$.

Carbon source

25 mM-sodium acetate +25 mM-glycerol

$50 \mathrm{~mm}$-sodium succinate

50 mM-glycerol

$50 \mathrm{~mm}$-glucose
Specific activity

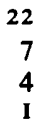

Table 6. Specific activities of acetate kinase and phosphotransacetylase in extracts of E. coli $\mathrm{K} 12$ strains $\mathrm{PA} 309$ and $\mathrm{K} 2.3$ (aceF) grown on various carbon sources

Cultures were grown, cell-free extracts were prepared and enzyme assays were carried out as described in Methods. Strain K2.3 was grown on medium containing 50 mM-glucose plus Io mMacetate. Strain PA309 was grown aerobically on the carbon sources at $25 \mathrm{~mm}$, and anaerobically on $25 \mathrm{~mm}$-glucose plus $25 \mathrm{~mm}$-sodium bicarbonate. Specific activities are expressed as $\mu$ mol hydroxamate or NADH formed min $^{-1}$ (mg protein $)^{-1}$.

\begin{tabular}{|c|c|c|}
\hline \multirow[b]{2}{*}{ Carbon source } & \multicolumn{2}{|c|}{ Specific activity } \\
\hline & Acetate kinase & $\begin{array}{l}\text { Phosphotrans- } \\
\text { acetylase }\end{array}$ \\
\hline \multicolumn{3}{|l|}{ PA309, aerobic } \\
\hline Glucose & $1 \cdot 5$ & $I \cdot 2$ \\
\hline Glycerol & $1 \cdot 3$ & $I \cdot 3$ \\
\hline Ribose & $1 \cdot 3$ & $1 \cdot 2$ \\
\hline L-Malate & $1 \cdot 7$ & $1 \cdot 5$ \\
\hline Acetate & $I \cdot 8$ & $1 \cdot 3$ \\
\hline Pyruvate & $4 \cdot 1$ & $2 \cdot 6$ \\
\hline DL-Lactate & $3 \cdot 7$ & $2 \cdot 8$ \\
\hline Gluconate & 3.6 & $2 \cdot 5$ \\
\hline Glucose/acetate & $1 \cdot 6$ & $2 \cdot 0$ \\
\hline \multicolumn{3}{|l|}{ K2.3, aerobic } \\
\hline Glucose/acetate & $3 \cdot 9$ & $3 \cdot 3$ \\
\hline \multicolumn{3}{|l|}{ PA309, anaerobic } \\
\hline Glucose & $4 \cdot 2$ & $5 \cdot 4$ \\
\hline
\end{tabular}

distinguishes it from the analogous succinyl-CoA synthetase (GDP-forming) [EC 6.2 . I .4] which is optimally active at $\mathrm{pH} \mathbf{7 \cdot 2}$, and from acetate kinase which has its $\mathrm{pH}$ optimum at $7 \cdot 4$.

The $K_{\mathrm{m}}$ and $V_{\max }$ values of the $E$. coli acetyl-CoA synthetase for coenzyme A and for ATP were measured with the hydroxamate assay (i). However, the amounts of hydroxamate formed at low concentrations of acetate were so small that this assay was useless for the determination of the $K_{\mathrm{m}}$ for acetate; for this purpose, the spectrophotometric coupled assay (ii) was used instead. The $K_{\mathrm{m}}$ for coenzyme A, at $3.3 \mathrm{~mm}$-ATP and 20 mM-sodium acetate, was $0.2 \mathrm{~mm}$ and the $V_{\max }$ was $100 \mathrm{nmol} \mathrm{m^{-1 }}$ (mg protein) ${ }^{-1}$. The $K_{\mathrm{m}}$ for ATP, at $0.3 \mathrm{~mm}-$ coenzyme $A$ and $20 \mathrm{~mm}$-sodium acetate, was $0.15 \mathrm{mM}$ with a $V_{\max }$ also of $100 \mathrm{nmol} \mathrm{m^{-1 }}$ $(\mathrm{mg} \text { protein })^{-1}$, whereas the $K_{\mathrm{m}}$ for acetate, at $0.5 \mathrm{mM}$-coenzyme $\mathrm{A}$ and $5 \mathrm{mM}-\mathrm{ATP}$, was $0.2 \mathrm{mM}$.

\section{Regulation of enzymes that effect the conversion of acetate to acetyl-CoA}

Although the properties of mutants impaired in acetate kinase or phosphotransacetylase activities strongly implicate these enzymes as playing a necessary role in the growth of $E$. colion acetate, these enzymes differ markedly from the acetyl-CoA synthetase that appears to effect the uptake of acetate from the medium with high affinity but with much lower 
$V_{\max }$. Thus, the $K_{\mathrm{m}}$ for acetate of acetyl-CoA synthetase (0.2 mM) is over $10^{3}$ times lower than the value of $0.3 \mathrm{M}$ reported by Rose et al. (I954) for acetate kinase. Moreover, whereas acetyl-CoA synthetase is inducible and is not produced to any significant extent by ack mutants grown in the absence of acetate (Table 5), the levels of acetate kinase and phosphotransacetylase found in extracts of wild-type $E$. coli vary little with carbon source (Table 6). Only after aerobic growth on pyruvate and on substrates catabolized largely to pyruvate (such as gluconate and lactate), or after anaerobic growth on glucose, do the cells contain these enzymes at specific activities about double those observed after growth on other substrates, including acetate. It is conceivable that pyruvate acts as an inducer, since the aerobic growth on glucose plus acetate of the $a c e F$ strain K2.3, which lacks pyruvate dehydrogenase activity and thus excretes pyruvate into the medium, is accompanied by synthesis of the two enzymes to about double the specific activity observed after the growth of wild-type cells under the same conditions.

\section{Location of the genes specifying acetate kinase (ack) and phosphotransacetylase ( $p t a)$ activities}

When a variety of different $\mathrm{Hfr}$ strains of $E$. coli (Low, 1973) were crossed with the pta mutant JM592, it was observed that the ability to grow on acetate appeared to be linked to the his marker when strain KLI6 (which transfers its genome to recipients in the order o-thyA-purF-his-trp-..) was the donor, but not when strain KL96 (which transfers its genome in the order o-his-trp-..) was used. This suggests that the pta marker was located between the origins of these two Hfr strains, i.e. between $\min 61$ and $\min 46$, on the $E$. coli linkage map.

In an attempt to determine the position more accurately, strain JM592 was mated in liquid medium with the Hfr strain PKI9I, which transfers its DNA in the direction o-his-purBthy $A-\ldots$ Mating was interrupted at intervals and samples were plated out to select $\mathrm{His}^{+}$ recombinants. These were then tested for resistance to fluoroacetate and for growth on acetate as carbon source. The two screening methods gave identical results: the first in $24 \mathrm{~h}$, the second in $72 \mathrm{~h}$. The appearance of fluoroacetate-sensitive, acetate-positive colonies in the sample taken $5 \mathrm{~min}$ after mixing the parental strains indicated that the pta locus was located in the vicinity of the $f p k$ or $p u r F$ markers, and might be cotransducible with one of them. Accordingly, bacteriophage PI $k c$ propagated on strain JM592 was used to transduce strain JM448 ( $p u r F f p k$ ) and adenine- or fructose-positive recombinants were selected. Of the adenine-positive colonies, 164 out of $240(68 \%)$ were fluoroacetate-resistant. In a parallel cross with PI grown on the ack strain JM59I as the donor, I 34 out of $240(56 \%)$ were resistant. However, none of the fructose-positive recombinants from either cross was fluoroacetate-resistant.

A fluoroacetate-resistant recombinant from each cross was assayed for phosphotransacetylase and acetate kinase activities, and shown to lack the function expected. Therefore both the pta and ack genes map at about min 50 on the $E$. coli chromosome.

In order to determine on which side of the purF locus these genes lie, strain AB2557 ( $d s d A$ aro $C$ pur $F$ ) was transduced with PI propagated on strain JM59I, and Dsd ${ }^{+}, \mathrm{Aro}^{+}$ and $\mathrm{Pur}^{+}$recombinants were selected. From each selection 240 colonies were tested for inheritance of the unselected markers. The results of this experiment, expressed as percentage cotransduction, are given in Fig. 4(a). Figure $4(b)$ indicates the percentage cotransduction with aroC in the parallel cross using PI grown on strain JM592 as the donor.

Though the results are compatible with the gene order indicated in Fig. 4 it should be noted that neither cross yielded an $\mathrm{Aro}^{+}$recombinant which was also Pur- but fluoroacetate-resistant (though some would be expected among the number analysed). It is therefore possible that one of the strains has a chromosomal inversion in the region under consideration. 


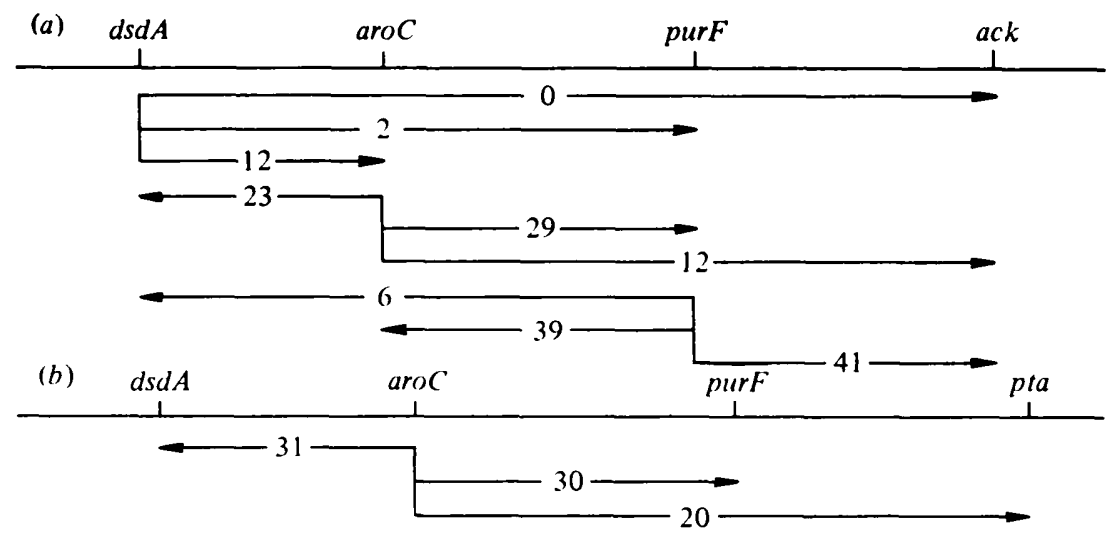

Fig. 4. Linkage of ack and pta to aro $C$ and purF. The numbers indicate the percentage cotransduction of the unselected marker.

\section{DISCUSSION}

The experiments described in this paper show that phosphotransacetylase plays a role in the excretion of acetate by $E$. coli growing on glucose: the enzyme is thus a catabolic one. No such role is evident for acetate kinase: ack mutants excrete acetate during aerobic growth on glucose and grow anaerobically on this hexose, both at rates closely similar to those observed with wild-type cells. The conversion of acetyl phosphate to acetate must therefore be possible under physiological conditions even in the absence of acetate kinase. It is likely that this is effected by non-enzymic hydrolysis of acetyl phosphate, which occurs rapidly at $37^{\circ} \mathrm{C}$ : no acetyl phosphate phosphatase activity was detected at either $\mathrm{pH} 7 \cdot 4$ or $\mathrm{pH} 5 \cdot 7$.

Mutants selected for tolerance to fluoroacetate were greatly impaired in their abilities to grow on acetate and were affected either in acetate kinase or phosphotransacetylase activities; since restoration of the missing enzyme function also restored growth on acetate, it is likely that these two enzymes also play an anabolic role in the utilization of exogenous acetate. It could be argued that the virtual inability of phosphotransacetylase mutants to grow on acetate might be due to growth stasis if acetyl phosphate were to accumulate from acetate: such inhibitions of growth by phosphorylated compounds are well documented (reviewed by Ferenci \& Kornberg, 1973). But the mode of selecting pta mutants demands that they are not inhibited by fluoroacetate during growth on proline or pyruvate; they are also not inhibited by acetate during growth on pyruvate or glycerol. Thus, there is no evidence against the view that phosphotransacetylase is involved in the utilization of acetate for growth. Similar conclusions were drawn from the study of ack and pta mutants of $K$. aerogenes reported by Brown, Pereira \& Størmer (1972).

Although $E$. coli mutants impaired in acetate kinase or phosphotransacetylase do not readily effect the mass conversion of acetate to acetyl-CoA that is required for growth on this $C_{2}$ compound, our results show that they are not devoid of the ability to incorporate ${ }^{14} \mathrm{C}$ from added $\left[2-{ }^{14} \mathrm{C}\right]$ acetate. An alternative route to acetyl-CoA must therefore operate to effect the uptake of labelled acetate from the medium and its incorporation into cell components. It is likely that this role is fulfilled by the inducible acetyl-CoA synthetase activity that we show to be present in extracts of mutants devoid of acetate kinase activity. But although the affinity of this enzyme for acetate $\left(K_{\mathrm{m}}=0.2 \mathrm{mM}\right)$ is of the same order as that of other enzymes involved in nutrient uptake, the maximal rate of acetyl-CoA formation it catalyses is far too low to account for the growth of wild-type $E$. coli on acetate. It is thus possible that, in a manner analogous to the several systems that can effect the uptake and 
growth of $E$. coli on galactose (reviewed by Kornberg, 1976), the acetyl-CoA synthetase plays primarily a role in scavenging acetate, present at relatively low concentrations in media (such as after growth on glucose), whereas acetate kinase and phosphotransacetylase normally play a catabolic role in effecting the excretion of acetate under these conditions but can also act in the opposite direction and effect the first step in the net conversion of acetate (albeit with low affinity) to cell components during growth.

We thank Dr B. J. Bachmann (CGSC) for the gift of E. coli strains, and the Science Research Council for supporting this work, through a studentship to T. D. K. Brown and through grant $\mathrm{B} / \mathrm{RG} / 97562$.

\section{REFERENCES}

Ashworth, J. M. \& Kornberg, H. L. (1966). The anaplerotic fixation of carbon dioxide by Escherichia coli. Proceedings of the Royal Society Br65, 179-188.

BachmanN, B. J., Low, K. B. \& TAYloR, A. L. (1976). Recalibrated linkage map of Escherichia coli K-1 2. Bacteriological Reviews 40, I 16-167.

BERG, P. (1956). Acyl adenylates: an enzymatic mechanism of acetate activation. Journal of Biological Chemistry 222, 99 I-IOI3.

Brown, T. D. K., Pereira, C. R. S. \& Størmer, F. C. (1972). Studies of the acetate kinase-phosphotransacetylase and the butane diol-forming systems in Aerobacter aerogenes. Journal of Bacteriology I12, 1 106-I I II.

Chou, T. C. \& LipmanN, F. (1952). Separation of acetyl transfer enzymes in pigeon liver extract. Journal of Biological Chemistry 196, 89-103.

Ferenci, T. \& KornberG, H. L. (I973). The utilization of fructose by Escherichia coli. Properties of a mutant defective in fructose $\mathrm{I}$-phosphate kinase activity. Biochemical Journal 132, 34I-347.

JoNes, M. E. \& LipManN, F. (I955). Aceto-CoAkinase. Methods in Enzymology I, 585-595.

JONES-MORTIMER, M. C. \& KORNBERG, H. L. (I974). Genetical analysis of fructose utilization by Escherichia coli. Proceedings of the Royal Society Br87, 12 I-I3I.

Kaplan, N. O. \& LipmanN, F. (1948). Reactions between acetate, acetyl phosphate and the adenylic system in tissue and bacterial extracts. Federation Proceedings 7, 163.

KorNberG, H. L. (1976). Genetics in the study of carbohydrate transport by bacteria. Journal of General Microbiology 96, 1-16.

KornberG, H. L. \& ReEves, R. E. (1972). Inducible phosphoenolpyruvate-dependent hexose phosphotransferase activities in Escherichia coli. Biochemical Journal 128, I339-1 344.
LipmanN, F. (1944). Enzymatic synthesis of acety phosphate. Journal of Biological Chemistry 155, 55-70.

LipmanN, F. \& Tuttle, L. C. (1945). A specific micromethod for the determination of acyl phosphates. Journal of Biological Chemistry 159, 2 I-28.

Low, K. B. (1973). Rapid mapping of conditional and auxotrophic mutations in Escherichia coli $\mathrm{K}-\mathrm{I}$ 2. Journal of Bacteriology 113, 798-8 12.

Lowry, O. H., Rosebrough, N. J., Farr, A. L. \& RANDALl, R. J. (I95I). Protein measurement with the Folin phenol reagent. Journal of Biological Chemistry 193, 265-275.

Mager, J., Goldblum-Sinai, J. \& Blank, I. (1955). Effect of fluoroacetic acid and allied fluoroanalogues on growth of Escherichia coli. I. Pattern of inhibition. Journal of Bacteriology 70, 320-325.

Marcus, A. \& ElliotT, W. B. (1959). Enzymatic reactions of fluoroacetyl phosphate. Journal of Biological Chemistry 234, IOI I-IOI4.

Miller, J. H. (1972). Experiments in Molecular Genetics. New York: Cold Spring Harbor Laboratory.

OCноА, S. (1955). Crystalline condensing enzyme from pig heart. Methods in Enzymology $1,685^{-}$ 694.

Overath, P., Pauli, G. \& Schatrer, H. U. (1969). Fatty acid degradation in Escherichia coli. An inducible acyl-CoA synthetase, the mapping of oldmutations, and the isolation of regulatory mutants. European Journal of Biochemistry 7, 559574.

Rose, I. A., Grunberg-Manago, M., Korey, S. R. \& OсHOA, S. (1954). Enzymatic phosphorylation of acetate. Journal of Biological Chemistry 211, 737-756.

Stadtman, E. R. \& Barker, H. A. (1950). Fatty acid synthesis by enzyme preparations of Clostridium kluyveri. VI. Reactions of acyl phosphates. Journal of Biological Chemistry 184, 769-793. 